\title{
RADIOCARBON DATING OF PALEOSEISMICITY ALONG AN EARTHQUAKE FAULT IN SOUTHERN ITALY
}

\author{
GILBERTO CALDERONI and VINCENZO PETRONE
}

Department of Earth Sciences, University of Rome I "La Sapienza"

Piazzale Aldo Moro, 5, 00100 Rome Italy

\begin{abstract}
On 23 November 1980, a major earthquake $\left(\mathrm{M}_{\mathrm{s}}=6.9\right)$ struck a large area of the southern Apennines (Campania and Lucania regions, southern Italy). This seismic event, the largest in Italy over the last 80 years, almost completely destroyed 15 villages and caused extensive damage to other towns, including Naples. The quake produced the first well-documented example in Italy of surface dislocation, represented by a fault scarp $38 \mathrm{~km}$ long. We undertook a study that included ${ }^{14} \mathrm{C}$ dating of organic materials from layers displaced by paleoseismic events to assess the seismologic hazard for the area. We collected peat and charred wood samples from the walls of two trenches excavated across the 1980 fault at Piano di Pecore di Colliano, Salerno, where the sedimentary suite is faulted and warped by five quakes (including that of 1980). This produced comparable vertical throw and deformation patterns. Chronological data for pre- 1980 events, coupled with detailed stratigraphic analysis, yielded a dip-slip rate and a recurrence interval of $0.4 \mathrm{~mm} / \mathrm{yr}$ and $1700 \mathrm{yr}$, respectively.
\end{abstract}

\section{INTRODUCTION}

The study of earthquakes is difficult in that, unlike many other naturally occurring geologic processes, seismic events, including those of higher magnitude, produce effects that only occasionally are preserved in the geologic records, and often, just within a narrow strip along the main fault systems. Terranes that undergo seismic shocks may develop a complex array of structural features, most of which are "seismites" (Seilacher 1969; Vittori, Sylos-Labini \& Serva 1988), which include faults, sandblows, folds and fissures. Regardless of pattern, seismites share a common origin that reflects the mechanical characteristics of the involved terranes, intensity of shock(s) and slipping displacement on a fault plane. Thus, survey of geologic structures attributable to seismic events (viz., seismite identification) is the primary fieldwork in paleoseismologic analysis. Seismite identification implies selecting the sites most favorable for their formation and preservation through time and differentiating them from non-seismic analogs. The latter task relies on geologists' experience, and the former is very difficult to accomplish, even in well-known seismic areas, owing to the rarity of obvious surficial faulting. This diagnostic geologic feature usually results only from quakes of magnitudes 6.0-6.5 with hypocenters from $<15$ to $20 \mathrm{~km}$ deep (Bonilla 1979; Bonilla, Mark \& Lienkaemper 1984). Surface geologic features produced occasionally by quakes of lower magnitude on unstable terranes are considered too unreliable for seismologic analysis. Thus, seismites are recognized mostly in suitable terranes close to active fault scarps.

It is reasonable to infer that, for a given fault system, earthquakes are non-random events displaying comparable patterns. Thus, in earthquake research, we need to understand paleoevents over a long time span to formulate consistent hypotheses and predictions. Studying the geologic records of seismites through the recent past is a viable approach to evaluating long-term behavior of active faults, which is essential in areas lacking long historical records of seismicity (Allen 1975). During the last two decades, geologists have used seismites preserved in young sediments for dating and for evaluating recurrence intervals and magnitudes of paleoevents (Sims 1973; Sieh 1978, 1984; Berger \& Kaufman 1980).

We discuss here the ${ }^{14} \mathrm{C}$ chronology of Holocene sediments close to the fault scarp produced by the 23 November 1980 Campania-Lucania earthquake, especially in terms of the late Holocene 


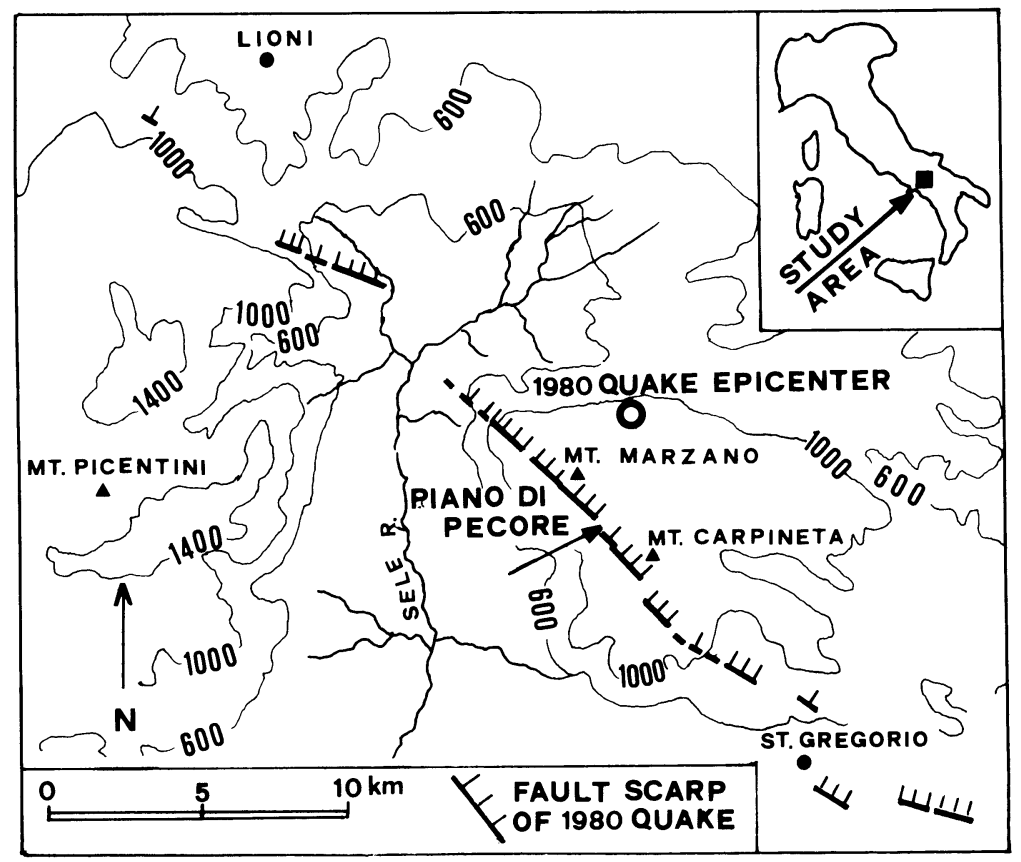

Fig. 1. Map of the study area showing a significant reach of the 1980 earthquake fault scarp, trending NW-SE.

seismic history along this active fault. In particular, we attempt to establish a time scale for the major prehistoric events and understand their pattern and recurrence interval.

\section{SAMPLING SITE AND MATERIALS}

We collected samples at Piano di Pecore di Colliano (1220 m asl, Salerno, southern Italy ( $44^{\circ} 44^{\prime} \mathrm{N}$, $15^{\circ} 22^{\prime} \mathrm{E}$ ) (Fig.1). The site is a small intermountain basin lying along the Mt. Marzano-Mt. Carpineta ridge, crossed by a southern segment of the 23 November 1980 fault scarp that shows ca. $80 \mathrm{~cm}$ of downthrow. We excavated two trenches with a backhoe in neighboring locations (Fig. 2) across the 1980 active fault. The trench walls expose a 4 -m-thick sequence of interbedded lacustrine and colluvial sediments along with air-borne volcanic materials. The profile, following detailed paleoseismologic analysis, revealed seismites (e.g., faultings and warpings) related to quakes before 1980. Figure 3 shows the stratigraphic column for Trench 1. Although the thickness of lacustrine and colluvial deposits changes according to trench location (e.g., colluvium and alluvium deposits maximize toward the rim and the center of the basin, respectively) all the exposures exhibit a common sedimentation pattern. The occurrence of volcanic ash and pumice is noteworthy, in that volcanites are lacking throughout the whole catchment area of the basin. Based on historical accounts (the topmost volcanic ash relates to the $1944 \mathrm{Mt}$. Vesuvius eruption), we infer that tephra at Piano di Pecore was ejected by Vesuvius and/or Phlegrean Fields from vents $c a$. $90 \mathrm{~km}$ to the northwest. Figure 3 gives the stratigraphic position for the analyzed samples, along with the identified sedimentary units. ${ }^{14} \mathrm{C}$ dated samples included charcoal, both scattered and in macrofragments, organic clay and a fibrous vegetal mat resembling peat, likely resulting from deposition and compaction of subaerial and lacustrine plant debris. Following routine pretreatment, the samples were converted to benzene and measured for ${ }^{14} \mathrm{C}$ activity by liquid scintillation counting with a $\beta$ spectrometer. Calderoni \& Petrone (1991) reported procedural details. 


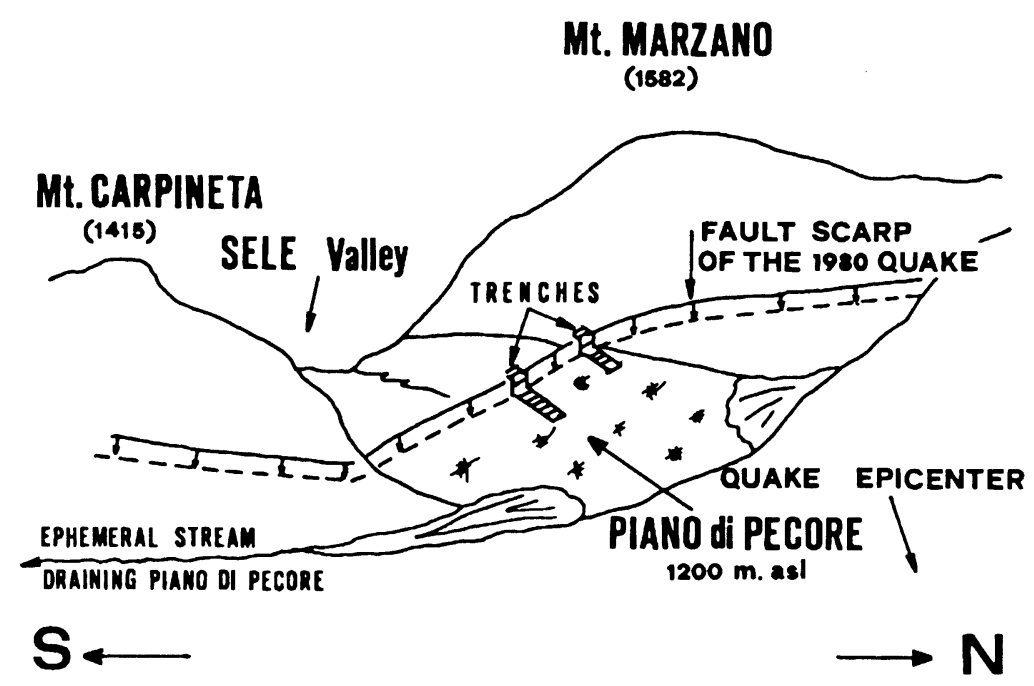

Fig. 2. Sketch of the trenching site depicting the morphologic changes following the 1980 event. The downthrow experienced by Piano di Pecore affected the former drainage toward Sele Valley, resulting in pond formation.

\section{RESULTS AND DISCUSSION}

The detailed paleoseismologic analysis of the geologic record in the trench walls at Piano di Pecore allows the depiction of the recent history of the surface fault produced by the 1980 earthquake. Principal findings include the identification of seismites resulting from 5 distinct events (including that of 1980) throughout the 8 sedimentary units occurring in the filling basin.

At Piano di Pecore, conditions for preserving the seismic imprinting were favorable over thousands of years. On the one hand, seismicity has ruptured the sediments repeatedly and, on the other, their rapid accumulation resulted in stratigraphic separation of the faulting events. Further, there have not been long sedimentation hiatuses or significant scour. Sedimentation rate, lack of erosion and preservation of carbonaceous materials were greatly enhanced by the acting tectonic mechanism, as well as by humidity. In fact, fault displacement associated with paleoseismic events recurrently ponded the basin by damming its ephemeral outpouring stream (Fig. 2), thus establishing a low-energy, reducing depositional environment where the solid input from the catchment area accumulated.

Analysis of the exposures in both trenches shows that subsurface sediments are significantly more displaced than the topographic surface produced by the 1980 earthquake, and that the amount of vertical displacement (= downthrow) increases with depth (= age). We argued that such a trend could be explained by the occurrence of pre-1980 events along the same seismic fault, which, in this respect, are supposedly comparable in tectonic style, genetic mechanisms and effects. The exposure in Trench 1 provided a better opportunity to characterize the paleoevents, in that we were able to make reliable comparisons, on both fault walls, among analogous packages (= sedimentary units) of sediment. Detailed analysis of the exposure revealed that the vertical separation of the stratigraphic units on the fault plane, rather than being constant, display a discontinuous character featuring four sudden increases. Each increment in throw, generally of an amount comparable to that of the 1980 surficial fault, involves one or more stratigraphic units. On this basis, the sharp throw increases were interpreted as records of seismic events and designated, top to bottom, from 


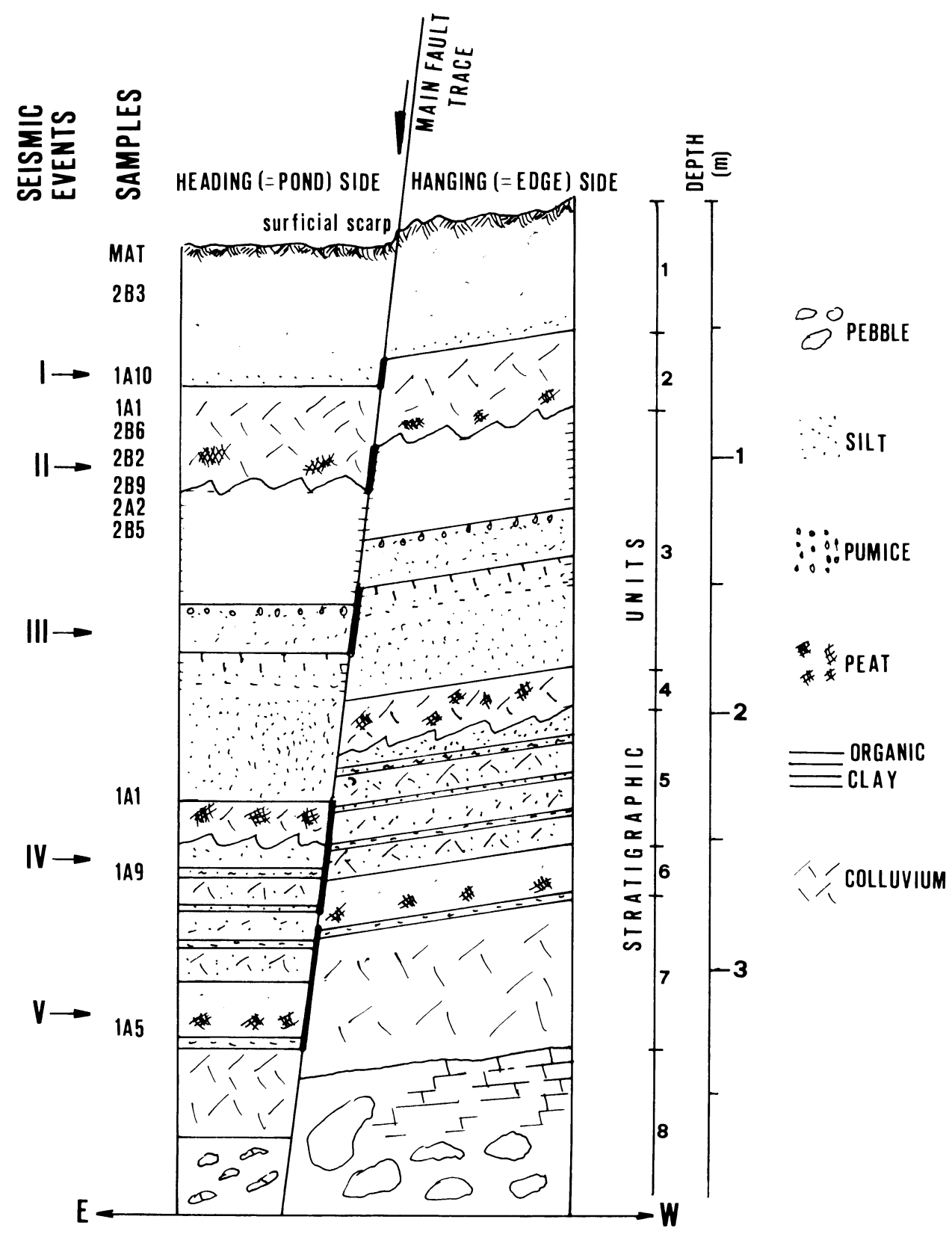

Fig. 3. Stratigraphy of the sampled exposure in Trench 1 showing both walls of the fault. The sedimentary suite consists mainly of peat-like organic debris, sandy, silty and clayey layers with scattered wood and charcoal fragments and pebbles. Location of samples and recognized seismic events, along with stratigraphic units, are reported to the left and right of the column, respectively. The recognized sharp throw increases, each referred to a seismic event, are represented by thicker segments on the trace of the main fault.

I (modern) through V (Fig. 3). We infer that each significant earthquake following Event $\mathrm{V}$ (the older event recognized) superimposed further vertical separation on the entire sedimentary suite existing at the time of its occurrence. To calculate the downthrow caused by individual paleoevents 
from the apparent vertical offsets, we iteratively subtracted the amount of displacement produced by the above-recorded earthquakes from those of Events II-V. The first subtraction $(80 \mathrm{~cm})$ was that of the surface fault scarp. The resulting throws, 50,50, 85 and $60 \mathrm{~cm}$ for Events II-V, respectively, apply only to the study site, as the magnitude of local displacement may change significantly along a seismic fault.

Among the samples collected during summer 1989, only 11 from Trench 1 were suitable, both in amount and reliability, for ${ }^{14} \mathrm{C}$ dating. The ages obtained, listed in Table 1 , provide a basic chronology for the identified paleoevents.

TABLE 1. Field, analytical and calculated data for the measured samples

\begin{tabular}{cclccc}
\hline Sample & Lab no. & \multicolumn{1}{c}{ Material } & $\begin{array}{l}\delta^{13} \mathrm{C} \\
(\%)\end{array}$ & ${ }^{14} \mathrm{C}$ age (BP) & $\begin{array}{c}\text { Calendar } \\
\text { age* }\end{array}$ \\
\hline MAT & Rome-124 & Surface debris & -25.5 & $102.2 \pm 0.5 \mathrm{pMC}$ & \\
2B3 & Rome-120 & Charcoal & -27.3 & $345 \pm 50$ & $475-305$ \\
1A10 & Rome-116 & Charcoal & -27.7 & $480 \pm 45$ & $535-500$ \\
1A1 & Rome-113 & Humified charcoal** & -24.8 & $1220 \pm 40$ & $1175-1065$ \\
2B6 & Rome-122 & Peat & -24.6 & $1550 \pm 50$ & $1515-1355$ \\
2B2 & Rome-119 & Humified charcoal** & -24.4 & $2620 \pm 45$ & $2760-2740$ \\
2B9 & Rome-123 & Charcoal & -23.3 & $2730 \pm 45$ & $2855-2770$ \\
2A2 & Rome-118 & Charcoal & -25.3 & $3100 \pm 80$ & $3380-3210$ \\
2B5 & Rome-121 & Organic clay & -25.0 & $3295 \pm 45$ & $3570-3465$ \\
1A1 & Rome-117 & Peaty-clay & -26.1 & $3850 \pm 55$ & $4400-4150$ \\
1A9 & Rome-115 & Peat & -26.0 & $3920 \pm 50$ & $4415-4275$ \\
1A5 & Rome-114 & Charcoal & -24.6 & $5900 \pm 50$ & $6780-6670$ \\
\hline
\end{tabular}

*Calibration according to Stuiver and Reimer (1993)

${ }^{* *} \mathrm{NaOH}$-soluble charcoal

\section{DATING THE PALEOEVENTS}

We summarize the data used in assigning each event a chronological constraint in Figure 3 and Tables 1 and 2.

Unit 1 - Soil. The topmost deposit is a coarse immature soil (sample MAT, altered surficial litter, yielded percent modern $(\mathrm{pMC})=102.2 \pm 0.5$ ) high in organic matter content. Descending, abundant pebbles occur, suggesting sedimentation under high-energy conditions. Sample $2 \mathrm{~B} 3$, tree roots in living position from the middle of the unit, and Sample 1A10, from the bottom, yielded $345 \pm 50 \mathrm{BP}$ and $480 \pm 45 \mathrm{BP}$, respectively. Unit 1 experienced only Event I (1980 earthquake, which produced an 80-cm-high surficial fault scarp).

Unit 2 - Colluvium. An ocher-colored deposit composed of reworked slopewash and volcanic material. Samples $1 \mathrm{~A} 1$ and 2B6, from the upper and middle part of the unit, were dated at 1220 $\pm 40 \mathrm{BP}$ and $1550 \pm 50 \mathrm{BP}$, respectively. Descending, the erosion of the fault scarp $(50 \mathrm{~cm}$ high) associated with Event II resulted in the formation of a typical colluvial wedge overlying Samples $2 \mathrm{~B} 2$ and $2 \mathrm{~B} 9$, dated at $2620 \pm 45 \mathrm{BP}$ and $2730 \pm 45$ BP, respectively (mean: $2675 \pm 30$ BP). Samples $2 A 2$ and $2 B 5$, just below the colluvial wedge, yielded $3100 \pm 80 \mathrm{BP}$ and $3300 \pm$ $45 \mathrm{BP}$, respectively (mean: $3250 \pm 40 \mathrm{BP}$ ). Thus, Event II is bracketed between $2675 \pm 30 \mathrm{BP}$ and $3250 \pm 40 \mathrm{BP}$.

Unit 3 - Upper Lacustrine. Both mineralogy and stratigraphy of the abundant volcanic tephra occurring here suggest that the Avellino eruption of Mt. Vesuvius (estimated at $3800 \mathrm{BP}$ ) was the 
TABLE 2. Ages of Seismic Events Along the Studied Seismogenetic System

\begin{tabular}{lcc}
\hline \multirow{2}{*}{ Event } & Upper limiting date (BP) & $\begin{array}{c}\text { Calendar age range* } \\
(\mathrm{BP})\end{array}$ \\
\hline I & Lower limiting date (BP) & 23 November 1980 \\
II & $\frac{2675 \pm 30}{3250 \pm 40}$ & $2755-3475$ \\
III & $\frac{3250 \pm 40}{3850 \pm 55}$ & $3400-4400$ \\
IV & $\frac{3920 \pm 50}{5900 \pm 50}$ & $4275-6780$ \\
V & $>5900 \pm 50$ & $>6780$ \\
\hline
\end{tabular}

*Calibration with software after Stuiver and Reimer (1993)

most likely source. Although no dates are available for the unit, the age of Event III, recorded here by $50 \mathrm{~cm}$ of vertical displacement, is constrained between $3250 \pm 40 \mathrm{BP}$ (mean of the ages for samples $2 \mathrm{~A} 2$ and $2 \mathrm{~B} 5$ ) and $3850 \pm 55 \mathrm{BP}$ (sample 1A11).

Unit 4 - Colluvium. Abundant weathered pumice and dark peaty layers occur through the deposit. Sample 1A11, at the top of the unit, was dated at $3850 \pm 55 \mathrm{BP}$.

Unit 5 - Lower Lacustrine. The unit includes graded sandy layers intercalated with thin clay beds. It exhibits the seismic imprinting of Event IV, represented here by faulting with an overall throw of $85 \mathrm{~cm}$. Sample 1A9, from the topmost clay level, was dated at $3920 \pm 50 \mathrm{BP}$. This age, along with that measured for Sample 1A5 $(5900 \pm 50 \mathrm{BP})$, provide chronological constraints on the occurrence of Event IV.

Unit 6 - Colluvium. A reddish, coarse colluvial deposit, rich in weathered pumice and containing scattered charcoal fragments. Descending, a thin lacustrine layer shows the Event V structural imprinting ( $c a .60 \mathrm{~cm}$ of vertical displacement) just overlying airborne tephra probably derived from an explosive eruption of Mt. Vesuvius (estimated at $7900 \mathrm{BP}$ ) responsible for the eastward spread of a pumice fall. Thus, according to stratigraphy, Event V is bracketed between $5900 \pm 45$ and 7900 BP. Sample $1 \mathrm{~A} 5$ provides the former age and overlies the seismite-bearing lacustrine layer. The latter date is a reasonable estimate for the age of the underlying tephra.

\section{CONCLUSION}

Paleoseismologic analysis coupled with ${ }^{14} \mathrm{C}$ dating of the geologic record exposed on the walls of two trenches excavated actoss an active seismic fault provided interesting data for earthquake research. We identified four seismite assemblages, each representing the imprinting of a paleoevent occurring along the same fault. As the displacements produced by the five quakes (including that of 1980) in the study area are comparable in both tectonic style and downthrow, we infer that the 1980 quake is "typical" for the investigated fault. In terms of seismic hazard, this means that quakes of comparable magnitude could recur.

For the first time in Italy, ${ }^{14} \mathrm{C}$ dating provided sound chronologic constraints on paleoevents, allowing the evaluation of quake recurrence intervals and slip rate for a representative site along the major Italian seismogenetic structure. Events I-IV took place over the last $6700 \mathrm{yr}$ and, based on stratigraphy, $<2000 \mathrm{yr}$ elapsed between Events IV and V. On this basis, calculations yielded a 
surficial slip rate of $0.4 \mathrm{~mm} \mathrm{yr}^{-1}$ for the fault (which, at depth, can increase dramatically) and $c a$. $1700 \mathrm{yr}$ as the mean recurrence interval.

\section{ACKNOWLEDGMENTS}

We are indebted to the National Institute of Geophysics (ING) for field data and sampling campaign. Funds were provided by Italian CNR, National Committee no. 5. The usual, friendly attitude of Dr. Meyer Rubin, USGS (Reston, Virginia) in improving the manuscript has been greatly appreciated.

\section{REFERENCES}

Allen, C. R. 1975 Geologic criteria for evaluating seismicity. Geological Society of America Bulletin 86: 1041-1057.

Berger, R. and Kaufman, T. S. 1980 Radiocarbon dating of earthquakes. In Stuiver, M. and Kra, R. S., eds., Proceedings of the 10 th International ${ }^{14} \mathrm{C}$ Conference. Radiocarbon 22(3): 746-756.

Bonilla, M. G. 1979 Historic surface faulting, map patterns, relation to subsurface faulting and relation to preexisting faults. In Proceedings of the 8th Conference on National Earthquake Hazard Reduction Program. USGS Open-File Report 79-1239: 36-65.

Bonilla, M. G., Mark, R. K. and Lienkaemper, J. J. 1984 Statistical relations among earthquake magnitude, surface rupture length and surface fault displacement. Bulletin of the Seismolological Society of America 74: 2379-2411.

Calderoni, G. and Petrone, V. 1992 Department of Earth Sciences at the University of Rome I radiocarbon

dates I. Radiocarbon 34(1): 105-113.

Seilacher, A. 1969 Fault-graded beds interpreted as seismites. Sedimentology 3: 155-159.

Sieh, K. E. 1978 Prehistoric large earthquakes produced by slip on the San Andrea fault at Pallet Creek, California. Journal of Geophysical Research 83: 3907-3939.

1984 Lateral offsets and revised dates of large prehistoric earthquakes at Pallet Creek, southern California. Journal of Geophysical Research 89: 7641-7670.

Sims, J. D. 1973 Earthquake-induced structures in sediments of Van Norman Lake, San Fernando, California. Science 182: 161-163.

Stuiver, M. and Reimer, P. J. 1993 Extended ${ }^{14} \mathrm{C}$ data base and revised Calib $3.0{ }^{14} \mathrm{C}$ age calibration program. Radiocarbon 35(1): 215-230.

Vittori, E., Sylos-Labini, S. and Serva, L. 1991 Paleoseismology: review of the state of the art. Tectonophysics 193: 9-32. 